\title{
Identification of the Sibling Species of the Blackfly, Simulium damnosum Complex Using their Polytene Chromosomal Banding Patterns in Oji River System, Enugu State, Nigeria
}

\section{Josephine Chiogo Ochu ${ }^{1}$, Ethel-Doris N. Umeh ${ }^{2}$ and Victor S. Njom ${ }^{3}$}

${ }^{1}$ Federal Ministry of Health, National Arbovirus and Vectors Research Centre (NAVRC), Enugu, Nigeria. E-mail address - (chio4ever2005@yahoo.com).

${ }^{2}$ Department of Applied Biology and Biotechnology, Enugu State University of Science and Technology, Enugu, Nigeria.

${ }^{3}$ Department of Applied Biology and Biotechnology, Enugu State University of Science and Technology, Enugu, Nigeria.

Cite this article:

Josephine C.O., Ethel-Doris N.U., Victor S.N. (2021), Identification of the Sibling Species of the Blackfly, Simulium damnosum Complex Using their Polytene Chromosomal Banding Patterns in Oji River System, Enugu State, Nigeria. African Journal of Biology and Medical Research 4(3), 69-78. DOI: 10.52589/AJBMR4ETST8KX.

\section{Manuscript History}

Received: 4 June 2021

Accepted: 30 June 2021

Published: 12 July 2021

Copyright $\odot 2020$ The Author(s). This is an Open Access article distributed under the terms of Creative Commons AttributionNonCommercial-NoDerivatives 4.0 International (CC BY-NC-ND 4.0 ), which permits anyone to share, use, reproduce and redistribute in any medium, provided the original author and source are credited.
ABSTRACT: Identification of the sibling species of the blackfly, S. damnosum complex using their polytene chromosomal banding patterns in Oji river system was carried out with the aim of accurately identifying the particular sibling species of $S$. damnosum complex involved in the transmission of onchocerciasis in Oji-river LGA and environ. Simulium damnosum complex larvae were collected monthly in forty eight (48) breeding sites in four sampling units for three years in the Oji river system in wet and dry seasons. Collected larvae were preserved in cold Carnoy's solution prior to processing. Salivary gland chromosomes were extracted, processed and analyzed microscopically for polytene chromosomal banding patterns. Three sibling species of Simulium damnosum complex that breed in the Oji river system were identified in varying degrees. They included S. squamosum, S. yahense and S. damnosum sensu stricto (s.s.). Variation in the occurrence of the sibling species was statistically significant. Dry and wet season catches for all the sibling species in the sampling units were found to differ statistically. The identified sibling species of $S$. damnosum complex are known to be vectors of Onchocerca volvulus, the causative agent of onchocerciasis, a disease highly prevalent in Oji-river LGA and environ.

KEYWORDS: Onchocerca volvulus, Onchocerciasis, Simulium, Polytene chromosomes. 


\section{INTRODUCTION}

The blackfly, Simulium damnosum complex is the vector of Onchocerca volvulus, the causative agent of river blindness (onchocerciasis) in West Africa. Onchocerciasis constitutes serious public-health and socio-economic problems in many rural parts of the world including Nigeria (Adeleke et al., 2010). Nigeria is one of the most onchocerciasis endemic countries in the world and accounts for one quarter of the global onchocerciasis infection (Oyibo and fagbenro, 2003). The disease causes significant morbidity, psychosocial problems (Ubachukwu, 2001) with reduced agricultural productivity in populations affected by the disease (Ubachukwu and Anya, 2001). In West Africa, including Nigeria, S. damnosum complex is found breeding in rapid sections of rivers and streams wider than 4 metres (Crosskey, 1990). The prevalence of infection could be attributed to the fact that many rivers and streams with favourable breeding sites abound in the affected areas and local farming practices make Simulium/human contact easy (Akogun and Onwuliri, 1991), (Abdullahi and Oyeyi, 2003).

S. damnosum complex has six main sibling species in West Africa. They are $S$. damnosum sensu stricto (s.s.), S. sirbanum, S. sanctipauli, S. soubrense, S. yahense and S. squamosum (WHO, 1995 and Post et al., 2007). Different species of $S$. damnosum complex are known to predominate the major vegetation zones (savannah and rainforest) in West Africa. $S$. damnosum s.s. and S. sirbanum for example are found mainly in the savannah regions and are therefore termed savannah species while the other four found in the rainforest zones of West Africa are termed rainforest species. The savannah forms transmit the parasite that causes mainly the eye-blinding type of onchocerciasis and the rainforest forms transmit the parasite that causes skin disease with less eye-blinding ((Mafuyai et al., 1996 and Ibeh et al., 2006).

The initial control of onchocerciasis focused on vector control by eliminating Simulium larvae in their breeding places using Dichloro-Diphenyl-Trichloroethane (DDT) - an organochlorine insecticide. DDT was found to be effective, and a good measure of success was recorded in the Onchocerciasis Control Programme (OCP) areas (WHO, 1995). However insect resistant biotypes that appeared wherever DDT was used regularly and intensely as well as the environmental hazards posed by the long persistence of DDT in the environment made its continued use unattractive. Nevertheless, vector control with the less persistent organophosphate insecticides is still in place (WHO, 1995).

Availability of ivermectin for human use since 1987 revolutionized onchocerciasis control in the sense that onchocerciasis became treatable and has been reported to have enormous clinical benefits (Borsboom, 2003). For onchocerciasis to be eliminated as a public-health problem, a combination of prophylactic (vector control) and chemotherapy (treatment with ivermectin) is needed (WHO, 1995).

The starting point of any vector control programme is proper identification of the target insect(s). In the case of Simulium damnosum complex with many sibling species, proper identification of the sibling species present will make the planning and actual management of the vector more targeted. Thus, the development and application of vector control will benefit more from a better understanding of the epidemiology of the disease, which will take into account the differences between the vector sibling species (Post et al., 2011). There are marked differences in the chromosomal banding patterns (Albert, 2008) of individual species of $S$. damnosum complex which could predict their innate ability to resist or be susceptible to insecticides. 
There were several reports of cytotaxonomic identification studies of the $S$. damnosum complex in Nigeria. Cytotaxonomic analysis of larvae of $S$. damnosum complex collected from twentythree sites across four bioclimatic zones in Nigeria revealed the presence of five sibling species which included S. damnosum s.s., S. sirbanum, S. squamosum, S. yahense and S. soubrense (Mafuyai et al., 1996). S. sirbanum was identified in Okpara River on the Nigeria-Benin border (Fiasorgbor and Cheke, 1992). In their studies, Ibeh et al. (2007) reported three species ( $S$. squamosum, S. yahense and S. damnosum s.s.); Ugwuanyi et al. (2015) reported four species (S. squamosum, S. yahense, S. damnosum s.s. and S. sirbanum) while Akoh et al. (1987) identified five species (S. squamosum, S. yahense, S. damnosum s.s., S. sirbanum and $S$. sanctipauli).

The purpose of this study therefore, is to accurately identify the particular sibling species of $S$. damnosum complex in Oji river system which are involved in the transmission of onchocerciasis in Oji-river LGA and environ. The findings will make the actual management of $S$. damnosum complex more targeted in the area.

\section{MATERIALS AND METHODS}

\section{Study area}

The study area runs along the Oji river system in Oji-river Local Government Area (L.G.A.) of Enugu State, southeast, Nigeria. Oji-river LGA is a semi-urban area located in the rainforest zone of southeast Nigeria. The geographical coordinates are $06^{\circ} 16^{\prime} \mathrm{N} 07^{\circ} 16^{\prime} \mathrm{E}$. There are two seasons: wet (April-October) and dry (November-March) seasons. Wet season has two rainfall peaks in July and September with a dry spell in August.

Four sampling units were selected along the Oji river system to search for larvae of Simulium damnosum complex. These were Adu-Achi $\left(06^{\circ} 19^{\prime} \mathrm{N} 07^{\circ} 34^{\prime} \mathrm{E}\right)$, Ahani-Achi $\left(06^{\circ} 20^{\prime} \mathrm{N} 07^{\circ}\right.$ $\left.32^{\prime} \mathrm{E}\right)$, Oji-urban $\left(06^{\circ} 26^{\prime} \mathrm{N} 07^{\circ} 27^{\prime} \mathrm{E}\right)$ and Okwe, Ugwuoba $\left(06^{\circ} 27^{\prime} \mathrm{N} 07^{\circ} 25^{\prime} \mathrm{E}\right)$.

\section{Search for the larvae of $S$. damnosum complex.}

Larval searches were carried out in twelve breeding sites in each sampling unit, and altogether, forty eight (48) breeding sites were extensively searched for the larvae of $S$. damnosum complex in the four sampling units monthly for three years (November 2015 - August 2018): November- March for dry season and April - August for wet season.

Simulium larvae attach themselves on submerged vegetation. Larval search therefore involved examining all the submerged life and dead vegetation in the breeding sites and all larvae found were picked using fine forceps and preserved in universal bottles containing cold Carnoy's solution (absolute ethanol and glacial acetic acid mixture of 3:1v/v). Carnoy's solution has the property of precipitating chromatin and prevents decomposition of the chromosomes (Boakye, 1993). The bottles were carefully labeled with the names of the breeding site and sampling unit where the larvae were collected. The larvae were then taken to the laboratory for morphological identification and analysis. 


\section{Morphological identification of $S$. damnosum complex}

The larvae were first examined under a dissecting microscope to ensure that they all belonged to $S$. damnosum complex and not other Simuliid flies. A diagnostic feature of S. damnosum complex larvae is the possession of protruding dorsal tubercles (Crosskey, 1960); presence of protruding dorsal tubercles was then used to isolate all $S$. damnosum complex larvae. Only mature larvae $\left(4^{\text {th }}-6^{\text {th }}\right.$ instar larvae $)$ were used for further work.

\section{Processing of larvae for chromosome preparation}

Processing of larvae for chromosome preparation was carried out using standard protocol modified by (Boakye, 1993). The larvae collected from each breeding site were dropped in a crucible containing $5 \mathrm{ml}$ of distilled water and washed by stirring the water gently for a minute with a stirring stick. Thereafter, the water was decanted and larvae were placed on a filter paper to blot excess water. Using fine forceps, each larva was picked and dropped into a labeled 10 $\mathrm{ml}$ specimen bottle containing lacto-acetic orcein stain for staining. The staining was allowed for three hours in a dark corner to increase the intensity of staining. Thereafter, the larvae were washed again in a crucible containing $5 \mathrm{ml}$ of distilled water. Each larva was picked and placed on a clean slide containing a drop of $50 \%$ glacial acetic acid. Under a dissecting microscope, the salivary gland of the larva was punctured with a fine entomological pin (No. 2) and the nuclei containing the polytene chromosome were pressed out with the entomological pin. The nuclei were then transferred onto another clean slide containing a drop of 50\% glacial acetic acid with the entomological pin and covered with a cover slip. By applying gentle pressure on the cover slip using the thumb, the polytene chromosome strands were distended to reveal its banding patterns.

\section{Identification of the sibling species of $S$. damnosum complex}

The distended polytene chromosomal strands were observed under a high powered stereo microscope (Motic BA 310) to check for their banding patterns. The observed banding patterns were compared with the chromosomal banding patterns in a pictorial guide by Boakye (1993) and the larvae were sorted into the sibling species they belonged to.

\section{Data analysis}

The data obtained from the studies were analyzed using Statistical Package for Social Sciences (SPSS version 21.0). One-way analysis of variance (Anova) was used to test the abundance of the sibling species of $S$. damnosum complex in the sampling units while chi-square was used to test the seasonal distribution of the sibling species of $S$. damnosum complex in the sampling units. Statistical significance was set at $\mathrm{P}<0.05$.

\section{RESULTS}

A total of $(\mathrm{n}=603)$ sibling species of $S$. damnosum complex which included $S$. damnosum s.s. S. squamosum and S. yahense were identified across the four sampling units in the study area. The abundance of these species in the sampling units shows that the highest population was identified in Adu-Achi followed by Ahani-Achi and Okwe, Ugwuoba. The least population of the sibling species identified was in Oji-urban. The difference in the abundance of the sibling 
African Journal of Biology and Medical Research

ISSN: 2689-534X

Volume 4, Issue 3, 2021 (pp. 69-78)

www.abjournals.org

species of $S$. damnosum complex identified across the four sampling units was statistically significant $(\mathrm{P}=0.0007)$ (Table I).

Table I: Abundance of the sibling species of $S$. damnosum complex in the sampling units.

\begin{tabular}{|c|c|c|c|c|}
\hline Sampling units & $\begin{array}{c}\text { S. damnosum s.s. } \\
\text { 'n' (\%) }\end{array}$ & $\begin{array}{c}\text { S. squamosum 'n' } \\
(\%)\end{array}$ & $\begin{array}{c}\text { S. yahense } \\
\text { 'n' }(\%)\end{array}$ & Total 'n' (\%) \\
\hline Adu-Achi & $27(32.14)$ & $133(32.92)$ & $25(21.74)$ & $185(30.68)$ \\
\hline Ahani-Achi & $23(27.38)$ & $109(26.98)$ & $39(33.91)$ & $171(28.36)$ \\
\hline Oji-urban & $17(20.24)$ & $52(12.87)$ & $18(15.65)$ & $87(14.43)$ \\
\hline Okwe, Ugwuoba & $17(20.24)$ & $110(27.23)$ & $33(28.70)$ & $160(26.53)$ \\
\hline Total & $84(13.93)$ & $404(67.00)$ & $115(19.07)$ & $603(100)$ \\
\hline
\end{tabular}

There was significant difference $(\mathrm{P}=0.029)$ in the distribution of the sibling species of $S$. damnosum complex in dry and wet seasons across the sampling units (Table II).

Table II: Seasonal distribution of the sibling species of $S$. damnosum complex in the sampling units.

\begin{tabular}{|c|c|c|c|c|c|}
\hline $\begin{array}{l}\text { Sampling } \\
\text { units }\end{array}$ & Season & $\begin{array}{c}\text { S. damnosum s.s. } \\
\text { 'n' }\end{array}$ & $\begin{array}{c}\text { S. squamosum } \\
\text { 'n' }\end{array}$ & $\begin{array}{c}\text { S. yahense } \\
\text { 'n' }\end{array}$ & $\begin{array}{c}\text { Total 'n' } \\
(\%)\end{array}$ \\
\hline Adu-Achi & Dry & 11 & 18 & 06 & $35(18.92)$ \\
& Wet & 16 & 115 & 19 & $150(81.08)$ \\
\hline Ahani-Achi & Dry & 08 & 18 & 06 & $32(18.71)$ \\
& Wet & 15 & 91 & 33 & $139(81.29)$ \\
\hline Oji-urban & Dry & 08 & 08 & 09 & $25(28.74)$ \\
& Wet & 09 & 44 & 09 & $62(71.26)$ \\
\hline $\begin{array}{c}\text { Okwe, } \\
\text { Ugwuoba }\end{array}$ & Dry & 05 & 13 & 03 & $21(13.12)$ \\
& Wet & 12 & 97 & 30 & $139(86.88)$ \\
\hline
\end{tabular}

The seasonal distribution of the sibling species of $S$. damnosum complex in the study area shows that greater numbers of the sibling species were identified in wet season than in dry season (Figure 1). 
African Journal of Biology and Medical Research ISSN: 2689-534X

Volume 4, Issue 3, 2021 (pp. 69-78)

www.abjournals.org

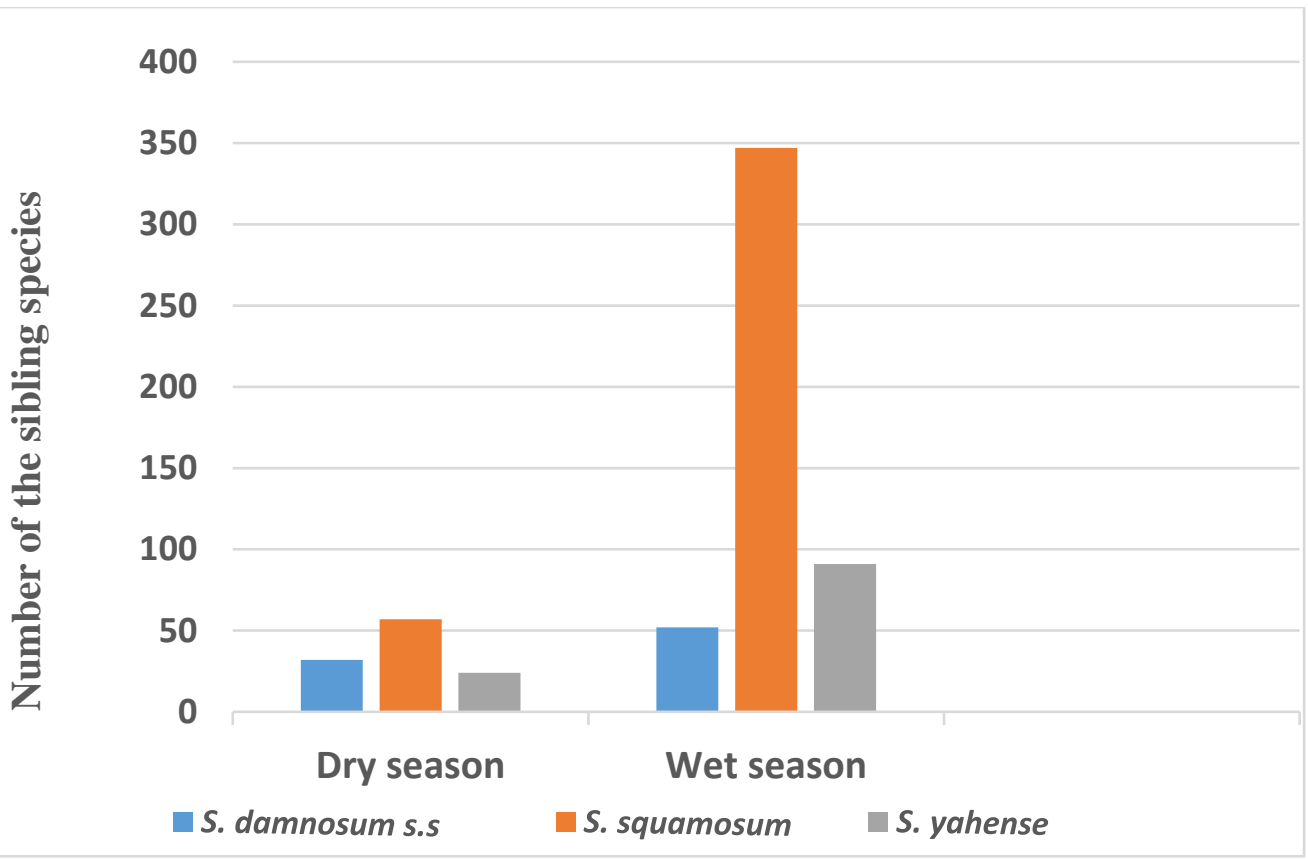

Figure 1: Seasonal distribution of the sibling species of $S$. damnosum complex in the study area.

The sibling species of $S$. damnosum complex were identified in varying degrees in the study area with $S$. squamosum being the most abundant species followed by $S$. yahense and $S$. damnosum s.s. (Figure 2).

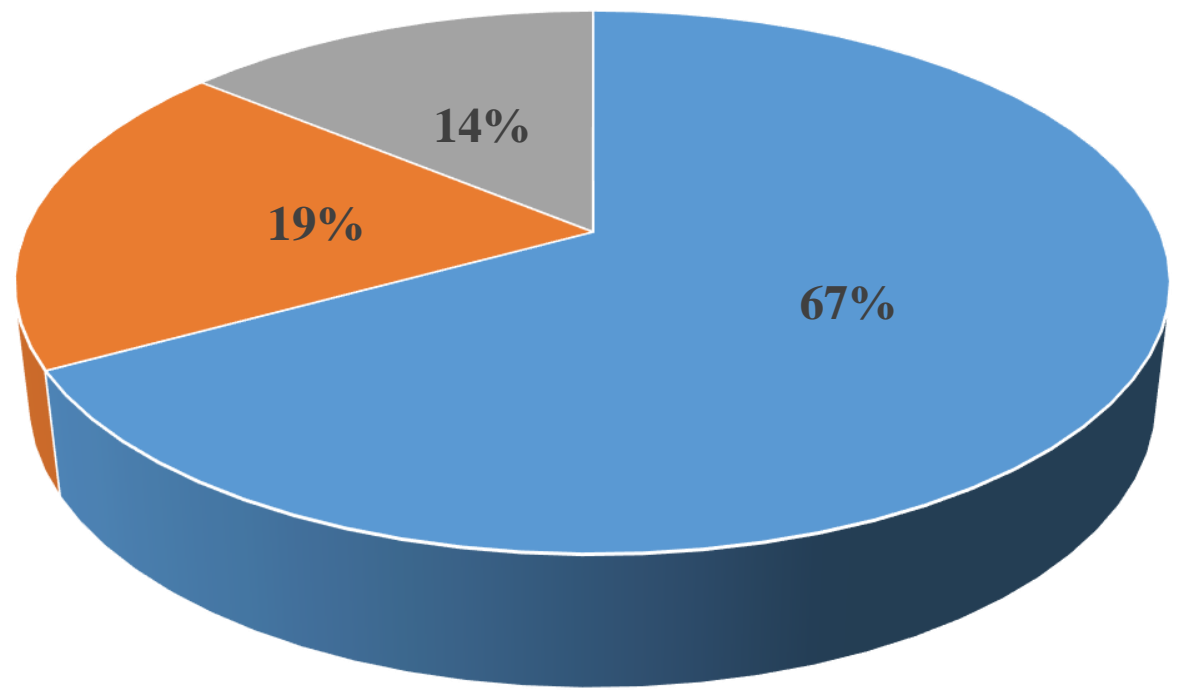

-S. squamosum $\quad$-S. yahense $\quad$ S. damnosum s.s

Figure 2: Percentages of the sibling species of $S$. damnosum complex identified in the study area. 


\section{DISCUSSION}

Out of the six sibling species of S. damnosum complex known to occur in West Africa, only three sibling species were identified in varying degrees in the study area. These were $S$. squamosum, S. damnosum s.s. and S. yahense (Figure 2). S. squamosum which was the most abundant sibling species collected in the study area differed significantly $(\mathrm{P}=0.0007)$ at $0.05 \%$ with the populations of the other two sibling species (Table I). The pattern of species distribution in this study follows the local ecology of the area which is a rainforest area. This result agrees with the findings in similar studies by (Ibeh et al., 2007 and Ugwuanyi et al., 2015) where $S$. squamosum was reported as the dominant vector breeding. S. squamosum has been known to be very widespread across Nigeria and is considered to be an efficient and important vector of Onchocerca volvulus in West Africa (Traore-Lamizana et al., 2001). The presence of $S$. damnosum s.s. (a savannah species) in the study area suggests that they could have invaded the area by migration from the savannah areas of Nigeria, and are capable of breeding in both rainforest and savannah areas. The implication of this finding is that both the eye-blinding and non-eye blinding strains of Onchocerca volvulus would be causing onchocercal disease in Oji-river LGA and environ.

There were seasonal variations in the abundance of the sibling species of $S$. damnosum complex in the study area. Their abundance fluctuated drastically between dry and wet seasons and were more in wet season than dry season (Figure 1). Dry and wet season catches for all the sibling species in the sampling units were found to differ statistically $(\mathrm{P}=0.029)$ at $0.05 \%$ (Table II). This finding is consistent with reports of (Opara et al., 2008) who reported high populations of $S$. damnosum complex in wet season but contrary to the findings by (Ugwuanyi et al., 2015 and Ibeh et al., 2006 \& 2007) who reported high populations of S. damnosum complex in dry season. The high abundance of the sibling species of $S$. damnosum complex observed in the wet season in the study area may be due to high water volume which increased the force of water at the breeding sites leading to optimal reproduction of Simulium flies. Also in wet season, more farming activities take place resulting in more fly/man contact to suck blood which eventually leads to increased reproduction of Simulium flies. The high abundance of the sibling species of $S$. damnosum complex recorded in three sampling units (Adu-Achi, AhaniAchi and Okwe, Ugwuoba) (Table II) could be that these areas are agrarian areas. Most of the inhabitants of these areas are farmers who stay long in their farms which are usually close to the river. They do most of their domestic activities (washing of clothes, cassava, bathing, fetching of water, etc.) in the river and these activities encourage fly/man contact which promote blood sucking and egg laying leading to increased productivity of Simulium flies.

On the contrary, the low abundance of the sibling species recorded in dry season could be as a result of the drying out of seasonal streams that feed the river which makes the force of water at the breeding sites to reduce. In the dry season, there are less farming activities and less fly/man contact to suck blood which leads to reduced reproduction of Simulium flies. The low abundance of the sibling species recorded in Oji-urban sampling unit (Table II) could be attributed to the fact that Oji-urban is an urban area with other sources of water like well-water, bore-hole, tap water etc. Many of the inhabitants of Oji-urban use these alternative sources of water instead of going to the river for their domestic activities. This therefore reduces fly/man contact which invariably reduces blood sucking and egg-laying by the flies leading to reduced productivity. Being an urban area, Oji-urban is more populated with many economic activities going on. The number of people living in an area is directly proportional to the waste they generate (Egunjobi, 1996). Some of the wastes generated in this area might be washed into the 
river from their dump sites during the rains thereby polluting the water which make the breeding sites non-conducive for the breeding of Simulium flies.

This study has revealed the breeding of three sibling species of $S$. damnosum complex which are vectors of the eye-blinding and non-eye blinding strains of Onchocerca volvulus in the study area. This finding will make the planning and actual management of the vector more targeted during vector control operations in the area.

Intensive vector control programmes and public enlightenment especially on human activities that encourage the breeding of blackflies are recommended. Further studies on the monitoring of any trend of change in the sibling species composition of $S$. damnosum complex in the study area and beyond are also recommended as knowledge of the species composition is a key to control of the vectors as well as the disease pathogens they transmit.

\section{Acknowledgement}

The authors are grateful to Prof. Daniel Boakye for his tireless efforts in making sure that we acquire the required skills in cytotaxonomic studies of $S$. damnosum complex. We are also grateful to the tour guides from the communities where the sampling units were selected for their guide during larval search using their good knowledge of the Oji river system. We thank the management of National Arbovirus and Vectors Research Centre, Enugu, Nigeria, for their logistics support in the conduct of this research.

\section{REFERENCES}

Abdullahi, Y. M. and Oyeyi, T. I. (2003). Current status of Onchocerciasis in Tudun Wada Doguwa Local Government Area of Kano State. Nigerian Journal of Parasitology, 24:77-88.

Adeleke, M. A., Olaoye, I. K. and Ayanwale, A. S. (2010). Socio-economic implications of Simulium damnosum complex infestations in some rural communities in Odeda Local Government Area of Ogun State. J. Public Health Epidemiol. 2(5): 109-112.

Akogun, O. B. and Onwuliri, C. O. (1991). Hyperendemic onchocerciasis in the Taraba valley of Gongola State (old Adamawa province), Nigeria. Annales de Parasitogie Humaine et Comparée, 6(1):22-26.

Akoh, J. I., Tada, I., Uchida, A., Sato, Y. and Hirai, H. (1987). Cytotaxonomic appraisal of the blackflies, Simulium damnosum s.l. Theobald (Diptera: Simuliidae) from different ecological zones of Nigeria. In proceedings of the Nigeria/Japan Joint Conference on Trace Metals, Diarrhoea, Goitre and Medical Entomology, 195-197. Jos, Nigeria: University of Jos.

Alberts, B., Johnson, A., Lewis, J., Raff, M., Roberts, K. and Walter, P. (2008). Molecular Biology of the cell. $5^{\text {th }}$ ed. New York: Garland Science.

Boakye, D. A. (1993). A pictorial guide to the chromosomal identification of members of the Simulium damnosum Theobald complex in West Africa with particular reference to the onchocerciasis control programme area. Tropical Medicine and Parasitology, 4:223244. 
Borsboom, G. J. M., Boatin, B. A., Nico, J. D., Nagelkerke, N. J. D., Agoua, H., Akpoboua, K. L. B., Soumbey-Alley, E. W., Bissan, Y., Renz, A., Yameogo, L., Remme, J. H. F. and Habbema, D. F. (2003). Impact of ivermectin on onchocerciasis transmission: assessing the empirical evidence that repeated ivermectin mass treatments may lead to elimination/eradication in West Africa. Filarial Journal, 28:122-138.

Crosskey, R. W. (1960). A taxonomic Study of the larvae of West African Simuliidae (Diptera: Nematocera) with comments on the morphology of the larval blackfly head. Bulletin of the British Museum (Natural History) (Entomology) 10:1-74.

Crosskey, R. W. (1990). The Natural History of Blackflies. British Museum (Natural History), London: John Wiley and Sons. 156pp.

Egunjobi, E. (1996). Fundamentals of Urban Administration in Nigeria. HRV Publishers. Fiasorgbor, G. K. and Cheke, R. A. (1992). Cytotaxonomic confirmation of two forms of Simulium sirbanum in the eastern part of the Onchocerciasis Control Programme in West Africa. Medical and Veterinary entomology, 6:139-142.

Ibeh, O. O., Nwoke, B. E. B. and Adegoke, J. A. (2007). Distribution and ecology of the breeding sites of Simulium damnosum s.l. in south eastern primary health zone of Nigeria. Nigerian Journal of Parasitology, 28:32-38

Ibeh, O. O., Nwoke, B. E. B., Adegoke, J. A. and Mafuyai, H. B. (2006). Cytospecies identifications of vectors of human onchocerciasis in south eastern Nigeria. African Journal of Biotechnology, 5:1813-1818.

Mafuyai, H. B., Post, R. J., Vajime, C. G. and Molyneux, D. H. (1996). Cytotaxonomic identification of the Simulium damnosum complex (Diptera: Simuliidae) from Nigeria. Trop. Med. Int. Health, 1:775-785.

Opara, K. N., Usip, L. P. and Akpabio, E. E. (2008). Transmission dynamics of Simulium damnosum in rural communities of Akwa Ibom State, Nigeria. Journal of Vector Borne Disease, 45:225-230.

Oyibo, W. A. and Fagbenro, B. (1998). An evaluation of community compliance with annual ivermectin treatment of onchocerciasis in Patigi, Nigeria. East African Medical Journal, 75(4):234-239.

Post, R. J., Mustapha, M. and Krueger A. (2007). Taxonomy and inventory of the cytospecies and cytotypes of the Simulium damnosum complex (Diptera: Simuliidae) in relation to onchocerciasis. Tropical Medicine and International health, 12(11):1342-1353.

Post, R. J., Onyenwe, E., Somari, S. A. E., Mafuyai, H. B., Crainey, J. L. and Ubachukwu, P. O. (2011). A guide to the Simulium damnosum complex (Diptera: Simuliidae) in Nigeria, with a cytotaxonomic key for the identification of the sibling species. Annal Trop. Med. Parasitol, 105(4):277-297.

Traore-Lamizana, M., Somiari, S., Mafuyai, H. B., Vajime, C. G. and Post, R. J. (2001). Sex chromosome variation and cytotaxonomy of the onchocerciasis vector Simulium squamosum in Cameroon and Nigeria: Medical and Veterinary Entomology, 15(2):219223.

Ubachukwu, P. O. (2001). Studies on Epidemiology and Effects of Human Onchocerciasis on Productivity and Social Lives of Rural Communities in Uzo-Uwani Local Government Area of Enugu State, Nigeria. PhD Thesis, University of Nigeria Nsukka. 
Ubachukwu, P. O. and Anya, A. O. (2001). Effects of Blackfly bites and manifestations of onchocerciasis in the productivity of farmers in Uzo-Uwani Local Government Area of Enugu State, Nigeria. Agro Science, 2(1):9-16.

Ugwuanyi, I. K., Eneanya, C. I., Nwaorgu, O. C., Aribodor, D. N., Mbanefo, E. C., Umeaneto, P. U., Egbuche, C. M. and Ugha C. N. (2015). Cytotaxonomic identification of Simulium damnosum complex (Diptera: Simuliidae) in Oji River area of Enugu State, Nigeria. Journal of Entomology and Zoology Studies, 3(3):34-39.

World Health Organisation (1995). Onchocerciasis and its control. Report of WHO Expert Committee on Onchocerciasis control. In World Health Organisation Tech Rep Ser, vol. 852. World Health Organisation, Geneva: 1-104. 